\title{
DO FOREIGN DIRECT INVESTMENT IN IVORY COAST INCREASE $\mathrm{CO}_{2}$ EMISSIONS?
}

\section{DOI: 10.17261/Pressacademia.2018.995 \\ JBEF- V.7-ISS.4-2018(4)-p.346-358}

\section{Maxime Tano Assi}

University of Peleforo Gon Coulibaly, Department of Economics, BP1328 Korhogo, Korhogo, Ivory Coast. tanass24@yahoo.fr

To cite this document

Assi, M. T. (2018). Do foreign direct investment in Ivory Coast increase $\mathrm{CO}_{2}$ emissions?. Journal of Business, Economics and Finance (JBEF), V.7(4), p.346- 358.

Permemant link to this document: http://doi.org/10.17261/Pressacademia.2018.995

Copyright: Published by PressAcademia and limited licenced re-use rights only.

\begin{abstract}
Purpose- In this paper, we study, on the basis of an endogenous growth model, the effect of foreign direct investment on $\mathrm{CO}_{2}$ emissions in Ivory Coast from 1975 to 2014.

Methodology- The preferred econometric tool is the ARDL model.

Findings- The results show a positive relationship between $\mathrm{CO}_{2}$ emissions and FDI whose associated coefficient is significantly different from zero in the short term. This result suggests that the contribution of FDI to $\mathrm{CO}_{2}$ emissions is minimal. Indeed, if FDI increases by 1 point (100\%) then $\mathrm{CO}_{2}$ emissions increase by $0.03 \%$. In the long term, the results suggest that the increase in FDI will lead to an increase in pollution with an associated coefficient significantly different from zero. As in the short term, this result also shows that the contribution of FDI to $\mathrm{CO}_{2}$ emissions is minimal in the long term. A 1 point increase in $\mathrm{FDI}(100 \%)$ leads to an increase in $\mathrm{CO}_{2}$ emissions of $0.14 \%$.

Conclusion- The improvement of the business, investment and trade climate in Ivory Coast, must be supported by social measures intended, in particular, to protect the health and safety of workers. Because environmental degradation due to an increase in emissions of $\mathrm{CO}_{2}$ supplies can have a negative impact on human health and bring about a decrease of economic growth.
\end{abstract}

Keywords: Foreign direct investment, $\mathrm{CO}_{2}$ emissions, growth, $\mathrm{ARDL}$, Ivory Coast.

JEL Codes: F20, O10, Q40

\section{INTRODUCTION}

According to UEMOA, foreign direct investment (FDI) is considered as "the purchase, creation or extension of businesses, branches or other personal enterprises". It is also "all other operations, where, isolated or multiple, concomitant or successive, they have the effect of allowing one or more persons to take or increase the control of a company engaged in an industrial, agricultural activity, commercial, financial or real estate, whatever its form, or to ensure the extension of such a company already under their control ". FDI therefore represents the installation of part of a firm's production abroad or the acquisition of a stake in a firm located abroad (Dago, 2010). The analysis of the relationship between FDI, growth and environment generates controversies about these virtuous effects on the one hand, and these vicious effects on the other hand.

First of all, as regards the virtues of FDI, four types of arguments concerning its relationship with growth and the environment theoretically justify them. The former is appreciated in terms of technology transfer and skills (Al-Mulali and Tang, 2013). The second is more traditional: it refers to the increase in job creation following the increase in direct investment (Strat, Davidescu and Paul, 2015) with a positive impact on growth (Nkechi, 2013). The third is the accumulation of human capital with the improvement in the quality of the labor force (Bahmaid, 2013; Ismaila, 2017). The fourth, finally, is the pollution hola hypothesis, which demonstrates that FDI provides advanced technology leading to the reduction of greenhouse gas emissions in host countries (Leiter, Parolini, and Winner, 2011; Zhang and Zhou, 2016), so countries have an interest in attracting FDI for their environmental quality through the absorption by local firms of a relatively cleaner technology transfer.

FDI can, however, be the source of vicious effects. Indeed, while it is accepted that FDI promotes economic growth, energy consumption can be proportional to growth. Thus, FDI can contribute to the degradation of the environment due to 
greenhouse gas emissions: this is the hypothesis of the pollution haven hypothesis (Mercan and Karakaya, 2015; Kheder and Zugravu, 2012). Increased environmental pollution can cause at least three adverse effects. The first concerns the reduction of production and therefore of income (Borhan, Ahmed and Hitam, 2012). The second focuses on the degradation of social well-being (Hitam and Borhan, 2012). The third is the decline in capital and labor productivity (Zivin and Neidell, 2012).

On the other hand, it is possible to argue that competitive pressures due to FDI can lead to crowding out of domestic investment (Morrissey and Udomkerdmongkol, 2012; Mutenyo, Asmah and Kalio, 2010) and pushing the least efficient firms to exit of the market, which could increase unemployment in the long term (Mucuk and Demirsel, 2013; Saray 2011) and reduce growth (Kyle and Miguel, 2015).

The impact of FDI on growth and the environment has been researched using the endogenous growth model at Romer (1986). Within these models, FDI is presented as an endogenous variable acting on economic growth via human capital, that is, knowledge, know-how and the knowledge to be incorporated by each individual. The divergence in the results of this work reveals the ambiguity of the relationship between FDI and growth on the one hand and FDI and the environment on the other.

On the basis of an endogenous growth model at Romer (1986), this article aims to examine how FDI affects $\mathrm{CO}_{2}$ emissions, which are key determinants of environmental degradation in Ivory Coast from 1975 to 2014.

The rest of the work is organized as follows: Review of the empirical literature (II); Descriptive analysis (III); Econometric approach and results (IV); Conclusion (V).

\section{EMPIRICAL LITERATURE}

While the theoretical results relating to the nature of the relationship between FDI, growth and the environment are nuanced, empirical evidence is even more so. It shows at least four cleavages. The first establishes a one-way relationship between energy consumption and growth. The second supports an increase in energy consumption due to economic growth. While the third shows a bidirectional relationship, the latter does not establish any causal relationship between energy consumption and economic growth. So what to think? Taking into account the hypotheses of the pollution haven and the Kuznets environmental curve makes it possible to better appreciate the relations between FDI, growth and the environment, and to explore both hypotheses. The answer is nuanced.

Firstly, in the case of the pollution haven hypothesis (HHP), it stipulates that the political and regulatory conditions favor the relocation of companies in order to benefit from environmental conditions that are less demanding than in their own territory contributes to the degradation of the environment.

The HHP has been tested by Al-Mulali and Tang (2013) who show that FDI does not contribute to environmental degradation in the case of the Gulf Cooperation Council countries between 1980- 2009. The authors note the existence of a non-linear relationship between $\mathrm{FDI}$ and $\mathrm{CO}_{2}$ emissions, which reflects the non-validation of HHP. Similarly, Lee and Brahmasrene (2013), using a cointegration model based on panel data, find that FDI has a negative and significant effect on $\mathrm{CO}_{2}$ emissions from 1988 to 2009 in the European Union. Leiter, Parolini, and Winner (2011) have already achieved such results by arguing that environmental regulations have been favorable for industrial investment in European countries between 1998-2007.

However, Blanco, Gonzalez and Ruiz (2013) argue for a unidirectional causal relationship between FDI and $\mathrm{CO}_{2}$ emissions where increased FDI causes $\mathrm{CO}_{2}$ emissions to increase in 18 Latin American countries. This result is confirmed by Zhang (2011) who notes an increase in $\mathrm{CO}_{2}$ emissions due to FDI in China between 1980 and 2009. The same is true for Middle Eastern countries where FDI has favored increase of the greenhouse gas between 1990-2009 according to Al-Mulali (2012).

In addition, $\mathrm{FDI}$ can promote both an increase and a reduction of $\mathrm{CO}_{2}$ emissions. Zeren (2015) tested this hypothesis and shows that HHP is validated for the United States, France and England and rejected in the case of Canada between 1970 and 2010.

On the other hand, it is possible that no statistically significant relationship is established between FDI and $\mathrm{CO}_{2}$ emissions. This is indeed the case in Turkey, where Kizilkaya (2017), based on a delayed autoregressive model (ARDL), finds no significant relationship between foreign direct investment and $\mathrm{CO}_{2}$ emissions during the period 1970-2014 because of the low contribution of FDI to GDP.

Regarding the Kuznets environmental curve hypothesis (EKC), Simon Kuznets argues that there is an inverted U-shaped relationship between per capita income and income equality. From this point of view, the EKC hypothesis states that the development process of all countries leads in the first place to the pollution of the environment. But at a certain level of per capita income, the process will be reversed with a reduction in environmental degradation. As income rises, individuals become more and more concerned about the quality of their environment and the improvement of their standard of living. 
The validity of the EKC was implemented by Tang and Tan (2015) on the basis of a Granger causality model. The authors demonstrated the existence of a bidirectional causal relationship between $\mathrm{CO}_{2}$ emissions and economic growth in Vietnam between 1976-2009. Kivyiro and Arminen (2014), on the other hand, highlight controversial results in the analysis of the relationships between $\mathrm{CO}_{2}$ emissions, energy consumption, economic development and $\mathrm{FDI}$ in six sub-Saharan African countries for the period 1970- 2009. On the basis of an ARDL model, if the EKC is validated for the Democratic Republic of the Congo, Kenya and Zimbabwe, this is not the case for South Africa, the Republic of Congo and Zambia. Similar results were obtained by Pao and Tsai (2011) who, based on panel data, note the existence of a bidirectional causal relationship between $\mathrm{CO}_{2}$ emissions and FDI on the one hand and causality unidirectional between GDP and FDI during the 1980-2000 period in the BRIC countries.

In addition, Arouri, Youssef, M'henni and Rault (2012), in the case of the 12 countries of the Middle East and North Africa highlight the validity of the EKC with low turning points in some cases and very high in others, between 1981 and 2005.

otherwise, some authors confirm both the validity of EKC and HHP in their analysis. Indeed, from an ARDL model, Thanh and Khuong (2017) show that economic growth, energy consumption, financial development, FDI and trade openness have a positive influence on $\mathrm{CO}_{2}$ emissions in Vietnam between 1990-2011. Similarly, Hitam and Borhan (2012) note an increase in $\mathrm{CO}_{2}$ due to the increase of the population in Vietnam. In other words, human activities through farming, forestry and mining contribute to the increase in GHG concentrations.

From one economy to another, the research shows a variety of results regarding the link between FDI, growth and the environment. These contradictory results stem from the type of explanatory variables, the choice of econometric model and the specificity of economies. What about Ivory Coast?

\section{DESCRIPTIVE ANALYSIS}

In Ivory Coast, most work on FDI is studying their impact on growth (Kyle and Miguel, 2015). Those relating to the effect of FDI on the environment are almost non-existent. This article is also intended to fill this gap. The interest in the relationship between FDI and the environment in Ivory Coast is justified mainly by two arguments. The first concerns the improvement of the business climate and the influx of FDI (Kyle and Miguel, 2015), which represent the key elements of the country's economic growth (AfDB, OECD and UNDP, 2016). And the second relates to pressures on natural resources (land, forests, water, etc.) (Tano, 2012) due to agricultural and industrial development.

\subsection{An Economy Highly Dependent on the Exploitation of Natural Resources}

According to the World Bank, agriculture accounts for about 30\% of GDP. The abusive and uncontrolled exploitation of natural resources has precipitated the degradation of the forest (Brou, 2010). Mainly, slash-and-burn techniques were the main sources of greenhouse gas emissions. Similarly, methane, carbon monoxide, nitrous oxide and nitrous oxide, agricultural residues and pesticides aggravate soil depletion (Aschieri and Lelievre, 2012) (Chart 1).

\section{Chart 1: Inventory of GHG Emissions Sources in Agriculture}

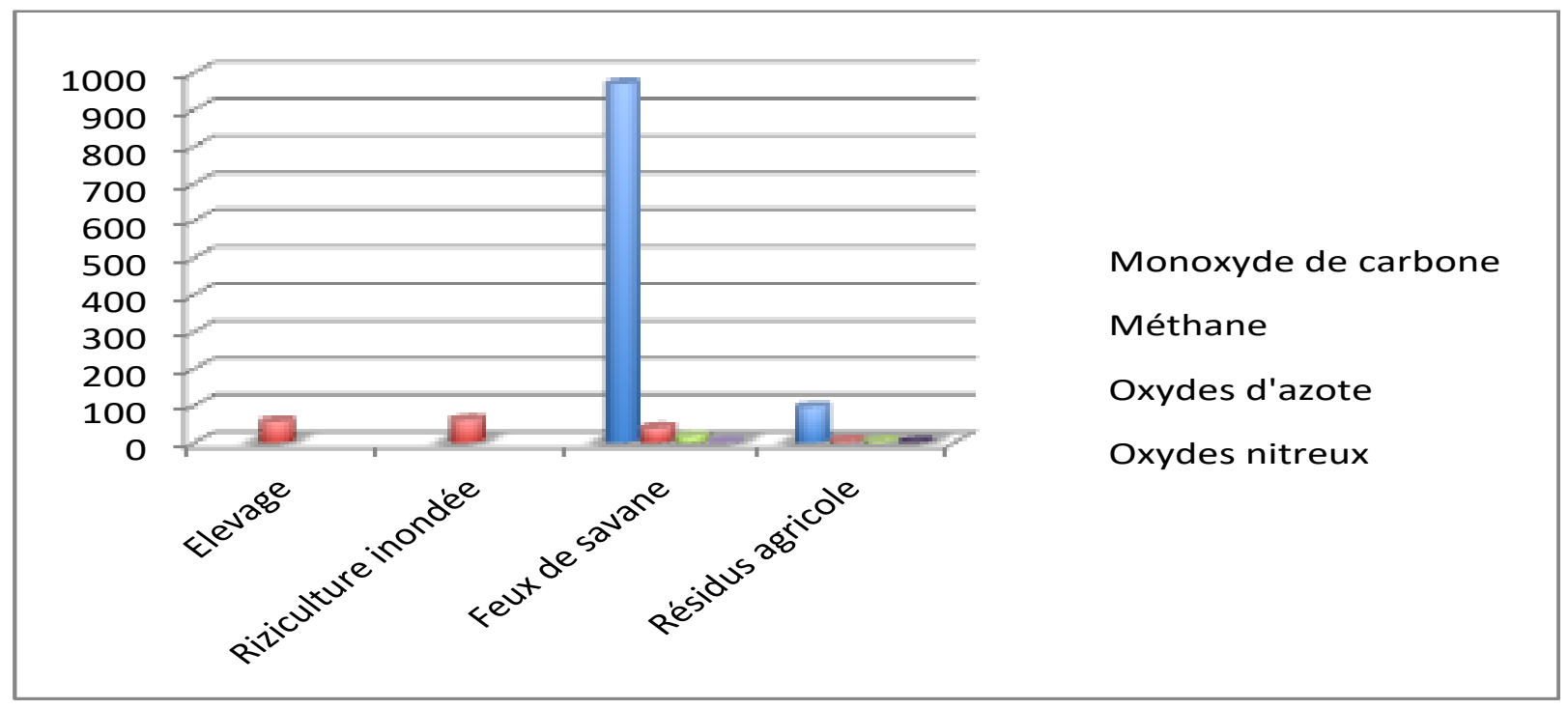

Source: Authors of the article, using MEF data (2000) 
In the industrial sector, improving the business climate in terms of business creation, contract enforcement and business regulation has provided incentives for the private sector, including FDI. Although their impact on growth is still mixed, the industrial sector composed of agri-food, chemical and biochemical industry, mining, textile and wood, contributes slightly to GHG emissions. The cement clinker is not produced locally, but is imported. This activity does not generate $\mathrm{CO}_{2}$ emissions. Other industrial units can be considered as minor sources of emissions.

\subsection{Descriptive Characteristics and Evolution of the Variables}

In terms of the Standard Deviation (Std Dev.) (Table 1), the analysis of the characteristics of the variables used shows that FDI and GDP are more volatile compared to other variables. This situation can be explained by the economic and politico-military crises that the country has been experiencing since the 1980s. To do this, Zivot and Andrews's stationarity test (1992) will be preferred to that of ADF for verification of the unit root of the GDP variable who is the victim of a change of regime. In addition, the variables are normally distributed (Jarque-Bera Prob>5\%), except the IDE variable.

Table 1: Descriptive Analysis of Variables

\begin{tabular}{|l|c|c|c|c|c|}
\hline & LNCO $_{2}$ & IDE & PIB & POP & LNOC \\
\hline Mean & -0.753040 & -21.58750 & 2.312500 & 3.183750 & 4.318520 \\
\hline Median & -0.787518 & -4.000000 & 1.745000 & 3.190000 & 4.333230 \\
\hline Maximum & -0.223144 & 468.5600 & 12.92000 & 4.760000 & 4.554613 \\
\hline Minimum & -1.272966 & -1515.650 & -10.96000 & 1.800000 & 4.013677 \\
\hline Std. Dev. & $\mathbf{0 . 2 7 6 6 6 8}$ & $\mathbf{2 5 9 . 8 4 6 9}$ & $\mathbf{4 . 5 8 6 3 3 7}$ & $\mathbf{0 . 9 5 5 9 9 0}$ & $\mathbf{0 . 1 4 5 5 3 6}$ \\
\hline Skewness & 0.163544 & -4.734986 & 0.005923 & 0.150049 & -0.349520 \\
\hline Kurtosis & 2.079829 & 29.09677 & 3.842661 & 1.682789 & 2.523618 \\
\hline & & & & & \\
\hline Jarque-Bera & 1.589502 & 1284.537 & 1.183698 & 3.041840 & 1.192660 \\
\hline Probability & $\mathbf{0 . 4 5 1 6 9 4}$ & $\mathbf{0 . 0 0 0 0 0 0}$ & $\mathbf{0 . 5 5 3 3 0 3}$ & $\mathbf{0 . 2 1 8 5 1 1}$ & $\mathbf{0 . 5 5 0 8 2 9}$ \\
\hline Sum & -30.12161 & -863.5000 & 92.50000 & 127.3500 & 172.7408 \\
\hline Sum Sq. Dev. & 2.985262 & $\mathbf{2 6 3 3 2 9 6 .}$ & 820.3450 & 35.64274 & 0.826054 \\
\hline Observations & 40 & 40 & 40 & 40 & 40 \\
\hline
\end{tabular}

Source: Author of the article from the results obtained on Eviews 9

Concerning the evolution of the variables, Chart 2 shows an overall stability of the latter between 1975 and 2014. However, the 1990s was particularly marked by a high degree of social and political instability, which led to a decline in wealth and FDI inflows. 


\section{Chart 2: Evolution of the Variables Studied}

LNCO2

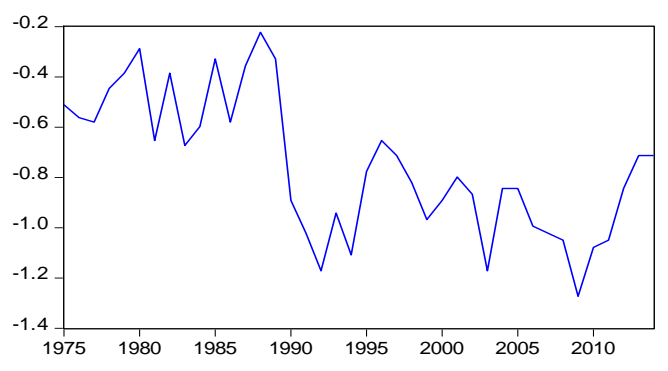

pib

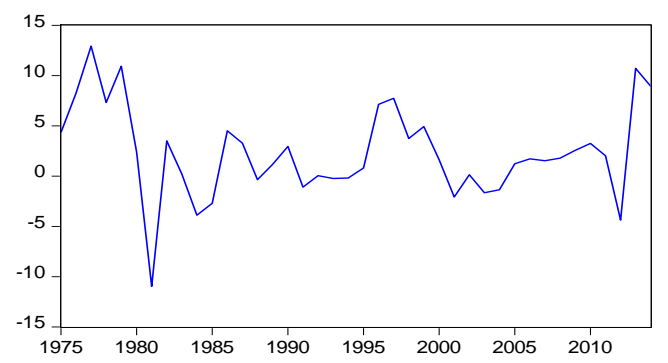

LNOC

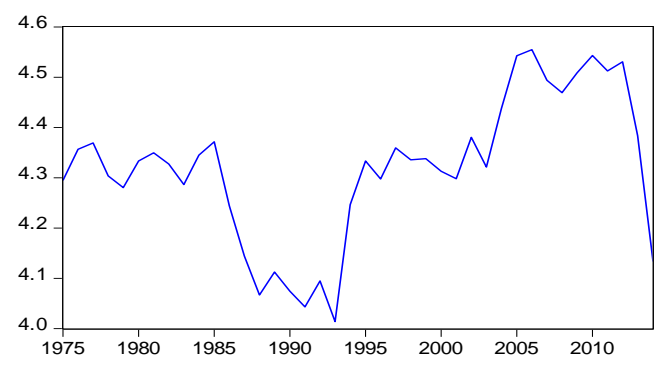

ide

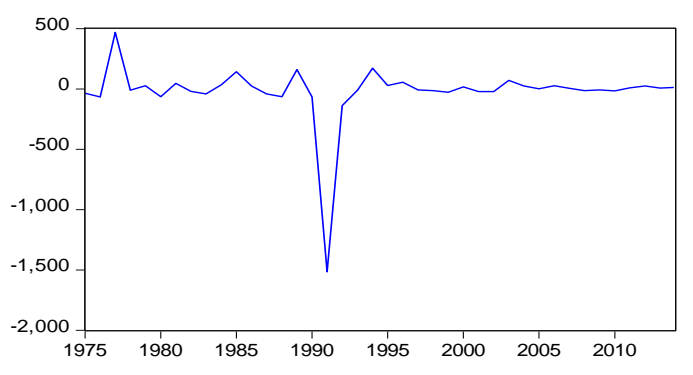

pop

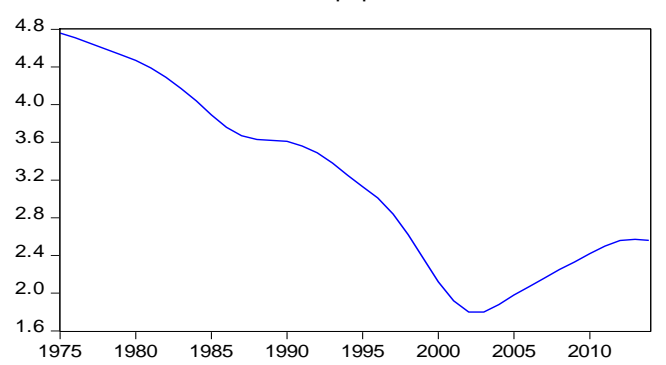

Source: Author of the article from the results obtained on Eviews 9

Regarding the impact of FDI on $\mathrm{CO}_{2}$ emissions in Ivory Coast, in order to ignore the aberrant value that prevents us from clearly reading the relationship between variables, we re-evaluated FDI in 1977 and 1991 in replacing them by the average of the observations in 1976 and 1978 and in 1990 and 1992 respectively for the data of 1977 and 1991.

\section{ECONOMETRIC APPROACH AND RESULTS}

We build on the work of Kizilkaya (2017), who has studied the relationship between carbon dioxide emissions and foreign direct investment in Turkey. But, unlike Kizilkaya (2017) who showed, on the basis of an ARDL model, the impact on $\mathrm{CO}_{2}$ emissions of growth and energy consumption, we are expanding the model and adapting it to case of Ivory Coast enriching it with an opening on the outside. We make the central assumption that in the long term, in Ivory Coast, the impact of FDI on $\mathrm{CO}_{2}$ emissions is positive between 1975 and 2014.

The analysis of the relationship between FDI and the environment presents the difficulty of having statistical data over a long period for Ivory Coast. This difficulty has led to the use of the World Bank's World Development Indicators (WDI) as the main source of data. We therefore constructed time series over the period 1975-2014, for a total of 40 observations. The variables in our model are as follows: The variable explained is greenhouse gas emissions. Any increase in this variable is a sign of environmental degradation with a negative impact on social well-being. The explanatory variables include: FDI, economic growth, trade openness and total population. To explain the source of the relationship between FDI and the environment, we build an endogenous growth model at Romer (1986) in which we consider FDI as the engine of growth. Thus, by calling 
(ide, oc, pib, pop) the explanatory variables for the dependent variable "greenhouse gas emissions" $\left(\mathrm{CO}_{2}\right)$, the functional form of the model is as follows:

$c o_{2 t}=f\left(i d e_{t}, o c_{t}, p i b_{t}, p o p_{t}\right)$,

with:

- $\mathrm{CO}_{2 t}$, Greenhouse gas emissions in period t ;

- ide, FDI valued from net inflows of FDI at period t ;

- $O C_{t}$, The commercial opening at period $\mathrm{t}$;

- pibt, Real economic growth in period t ;

- popt $_{t}$, The total population at period t.

\subsection{Econometric Approach}

The preferred econometric tool is the ARDL method. At least three reasons justify such a choice.

$1^{\circ}$ ) ARDL is better suited for small sample sizes (Pesaran, Shin and Smith, 2001), whereas some techniques, such as Johansen cointegration, require a large sample to obtain a valid result (Ghatak and Siddiki, 2001);

$2^{\circ}$ ) the ARDL can be applied if the variables used are all I (1), I (0), or mixed;

$3^{\circ}$ ) The ARDL requires a reduced and simple form of the equation while other techniques will require a system of equations (Pesaran and Shin, 1999).

$\ln \mathrm{c}_{2 t}={ }_{0}+{ }_{1} i d e_{t}+{ }_{2} p i b_{t}+{ }_{3} \ln O c_{t}+{ }_{4} p o p+{ }_{t}{ }_{t}$,

where, in addition to the previous notations, i represents the semi elasticities of the model to be estimated which express the sensitivity of the explained variable to the explanatory variables. ${ }_{i}(i=0 \ldots 4)$, with ${ }_{0}$ constancy and ${ }_{t}$, the error term at period t.

At least two arguments make it possible to justify such a presentation of the model. The first relates to the problem of nonnormality, which is reduced with variables expressed in logarithmic form (Wooldridge, 2006). The second concerns the problem of endogeneity, which is solved because of delayed dependent variables as regressors (Wooldridge, 2006).

The error correction model of the ARDL model is as follows:

$$
\begin{aligned}
& \ln c Q_{2 t}={ }_{0}+\sum_{i=1}^{21}{ }_{1} \ln c_{2 t}+\sum_{i=1}^{2 n}{ }_{2} i d e_{i}+\sum_{i=1}^{23}{ }_{3} p i b_{t i}+\sum_{i=1}^{24}{ }_{4} \ln O c_{t i} \\
& +\sum_{i=1}^{25}{ }_{5} \mathrm{pop}_{t i}+{ }_{1} \ln \mathrm{CO}_{2 t i}+{ }_{2} i d e_{11}+{ }_{3} \mathrm{pib}_{t 1}+{ }_{4} \ln O \mathrm{C}_{t 1}+{ }_{5} \mathrm{pOp}_{t 1}+{ }_{t}
\end{aligned}
$$

where, in addition to the previous notations, $\Delta$ is the first difference operator. $\quad{ }_{i}(i=0 . .5)$ represents the short-term dynamics of the model while ${ }_{i}(i=0 . . .5)$ represents the long-term relationship.

We will proceed in three stages.The first presents the unit root tests. It will be necessary to determine the order of integration of the variables. These tests are made from the ADF and AZ test. The second step concerns the cointegration test. The Engle-Granger two-step method (1987) will test the cointegration relationship between variables. After showing that the variables of interest are cointegrated, the third step, finally, relates to the analysis of the long and short-term dynamics between the variables of the model.

\subsubsection{Stationarity of Series}

The table 2 shows that all the series are integrated of order 1, except the IDE which is stationary at level. The series being integrated at different orders, the conditions required to perform the cointegration test at the Pesaran, Shin and Smith (2001) terminals are satisfied. However, applying the Bound test requires at least two steps. This is the determination of the optimal offset and the use of the Fisher test to test cointegration between series. 
Table 2: Unit Root Tests

\begin{tabular}{|c|c|c|c|c|c|c|c|}
\hline & \multicolumn{3}{|c|}{ Level } & \multicolumn{3}{|c|}{ First difference } & \multirow[b]{2}{*}{ Constat } \\
\hline & $A D F$ & $A Z$ & $\begin{array}{l}\text { Date de } \\
\text { rupture/AZ }\end{array}$ & ADF & $A Z$ & $\begin{array}{l}\text { Date de } \\
\text { rupture/AZ }\end{array}$ & \\
\hline LNCO2 & $\begin{array}{l}-3.10 \\
(0.12)\end{array}$ & $-5.41 \quad(0.08)$ & 1989 & $\begin{array}{l}-7.31 \\
(0.00)\end{array}$ & $-8.29(0.01)$ & 1990 & $\mathrm{I}(1)$ \\
\hline IDE & $\begin{array}{l}-5.46 \\
(0.00) \\
\end{array}$ & $\begin{array}{l}-15.71 \\
(0.01) \\
\end{array}$ & 1991 & - & - & - & $I(0)$ \\
\hline PIB & $\begin{array}{l}-3.96^{* * *} \\
(0.01)\end{array}$ & $\begin{array}{l}-5.30 * * * \\
(0.03)\end{array}$ & 2012 & $\begin{array}{l}-7.42 \\
(0.00)\end{array}$ & $\begin{array}{l}-7.79 \\
(0.01)\end{array}$ & 1989 & $\mathrm{I}(1)$ \\
\hline LNOC & $\begin{array}{l}-1.35 \\
(0.85)\end{array}$ & $-1.72 \quad(0.99)$ & 1993 & $\begin{array}{l}-4.27 \\
(0.00) \\
\end{array}$ & $\begin{array}{l}-6.00 \\
(0.01) \\
\end{array}$ & 2011 & $\mathrm{I}(1)$ \\
\hline POP & $\begin{array}{l}-1.27 \\
(0.87) \\
\end{array}$ & $\begin{array}{l}-4.61 \\
(0.18) \\
\end{array}$ & 1996 & $\begin{array}{l}-3.75^{* * *} \\
(0.03) \\
\end{array}$ & $\begin{array}{l}-5.81 \\
(0.01) \\
\end{array}$ & 1995 & $\mathrm{I}(1)$ \\
\hline
\end{tabular}

Source: Synthesis of the Author from the results obtained on Eviews 9

(.) Probabilities; *** Stationary at 5 and $10 \%$.

\subsubsection{Optimal Offset and Estimation of the ARDL Model}

For the choice of the optimal ARDL model, nameley the one that offers statistically significant results, we used the Schwarz (SIC) and Akaike (AIC) information criterion (Table 3).

\section{Table 3: Optimum Offset Number}

\begin{tabular}{|c|c|c|c|c|c|c|}
\hline \multicolumn{7}{|c|}{ VAR Lag Order Selection Criteria } \\
\hline \multicolumn{7}{|c|}{ Endogenous variables: LNCO2 IDE PIB POP LNOC } \\
\hline \multicolumn{7}{|c|}{\begin{tabular}{|l|l|} 
Exogenous variables: $\mathrm{C}$ & \\
\end{tabular}} \\
\hline \multicolumn{7}{|c|}{ Included observations: 35} \\
\hline Lag & LogL & LR & FPE & AIC & SC & HQ \\
\hline 0 & -353.1326 & NA & 531.3459 & 20.46472 & 20.68691 & 20.54142 \\
\hline 1 & -244.1204 & 180.6488 & 4.444795 & 15.66402 & 16.99718 & 16.12423 \\
\hline 2 & -176.9177 & 92.16369 & 0.437419 & 13.25244 & 15.69656 & 14.09615 \\
\hline 3 & -128.5151 & $52.55137^{*}$ & 0.148269 & 11.91515 & 15.47023 & 13.14236 \\
\hline 4 & -84.23030 & 35.42787 & 0.086748 & 10.81316 & 15.47920 & 12.42388 \\
\hline 5 & -16.38517 & 34.89178 & $0.025101^{*}$ & 8.364867* & 14.14187* & $10.35909 *$ \\
\hline
\end{tabular}

Source: Synthesis of the Author from the results obtained on Eviews 9

The offset number used corresponds to the lowest value of the AIC and SIC criteria, namely $h=5$.

The result of the estimation of the optimal ARDL model is given in the following table.

Table 4: ARDL model $(1,3,0,0,0)$

\begin{tabular}{|l|c|c|c|c|}
\hline \multicolumn{4}{|l|}{ Dependent Variable: LNCO2 } & \\
\hline \multicolumn{2}{|l|}{ Selected Model: ARDL (1, 3, 0, 0, 0) } & \\
\hline Variable & Coefficient & Std. Error & t-Statistic & Prob. $^{*}$ \\
\hline LNCO2(-1) & 0.038519 & 0.169558 & 0.227170 & 0.8219 \\
\hline IDE & 0.000380 & 0.000121 & 3.139613 & 0.0040 \\
\hline IDE(-1) & 0.000374 & 0.000108 & 3.473201 & 0.0017 \\
\hline IDE(-2) & 0.000257 & 0.000128 & 2.003056 & 0.0549 \\
\hline IDE(-3) & 0.000343 & $9.90 \mathrm{E}-05$ & 3.461266 & 0.0017 \\
\hline PIB & -0.002921 & 0.006144 & -0.475382 & 0.6382 \\
\hline POP & 0.158851 & 0.038543 & 4.121377 & 0.0003 \\
\hline LNOC & -0.636960 & 0.279332 & -2.280293 & 0.0304 \\
\hline C & 1.563598 & 1.145453 & 1.365048 & 0.1831 \\
\hline
\end{tabular}




\begin{tabular}{|l|l|c|c|}
\hline R-squared & $\mathbf{0 . 7 5 0 6 5 4}$ & Durbin-Watson stat & 2.192093 \\
\hline Adjusted R-squared & 0.679412 & F-statistic & 10.53671 \\
\hline Prob(F-statistic) & 0.000001 & & \\
\hline
\end{tabular}

Source: Synthesis of the Author from the results obtained on Eviews 9

The Chart 3 shows the twenty best models according to the Schwarz information criterion. The ARDL model $(1,3,0,0,0)$ is actually the smallest $\mathrm{CIS}$ value.

Chart 3: Schwarz Information Criterion (SIC).

Schwarz Criteria (top 20 models)

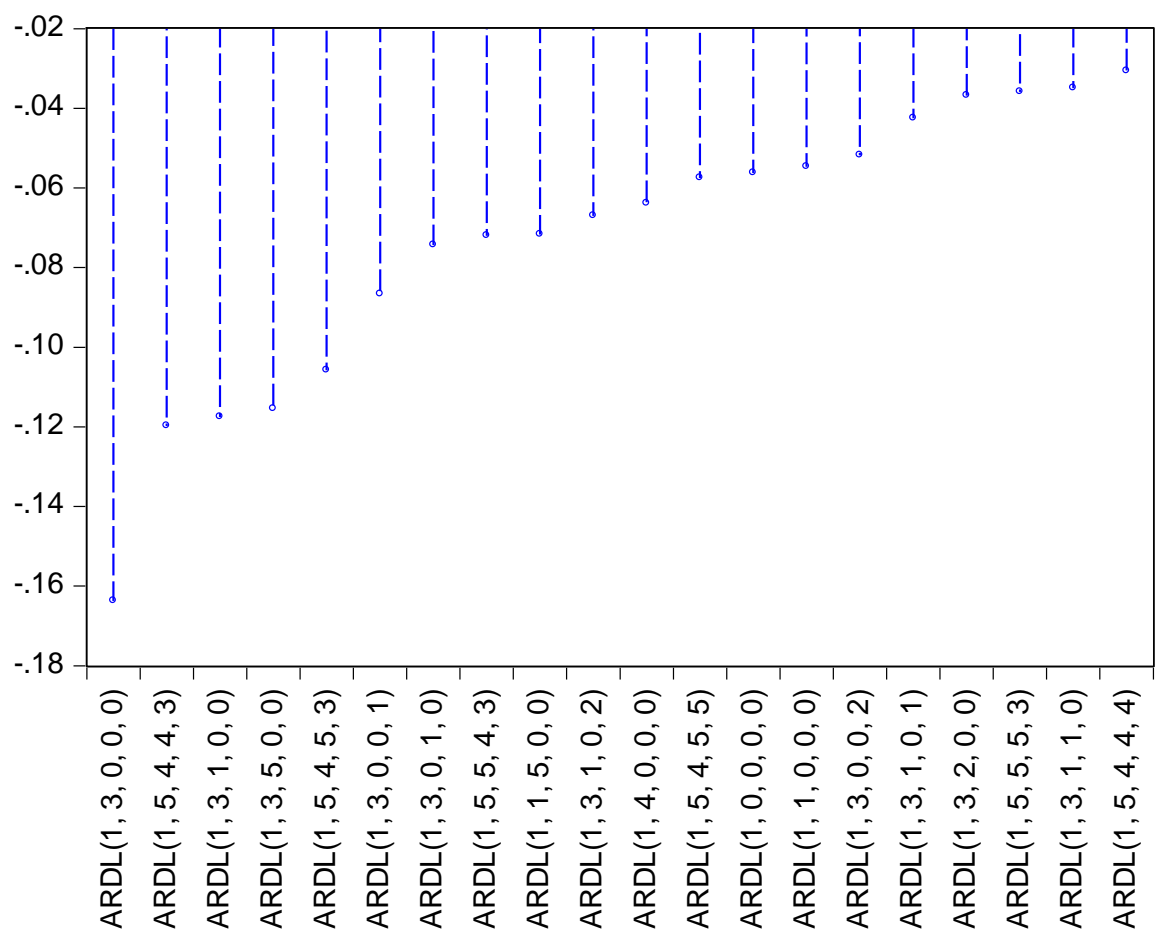

Source: Author from the results of the Eviews 9 software

The ARDL model estimated from the autocorrelation, heteroskedasticity, normality and specification tests should now be diagnosed (Table 5).

\subsubsection{Model Diagnostic Tests}

As the probability values are greater than $5 \%$, the null hypothesis is accepted for all the tests. We therefore conclude that the model is statistically validated. Thus, the $\operatorname{ARDL}$ model $(1,3,0,0,0)$ is globally good and accounts for $75 \%$ of $\mathrm{CO}_{2}$ dynamics in Ivory Coast between 1975 and 2014.

\section{Table 5: Diagnostic Tests of the Estimated ARDL Model}

\begin{tabular}{|l|l|l|l|}
\hline Null Hypothesys & Tests & Values (Probability) & Conclusion \\
\hline Absence of autocorrelation & $\begin{array}{l}\text { Breusch-Godfrey (F- } \\
\text { Stat) }\end{array}$ & 1.41 (Prob. 0.25) & Absence of autocorrelation \\
\hline Homocedastic errors & $\begin{array}{l}\text { Breusch-Pagan- } \\
\text { Godfrey }\end{array}$ & 0.65 (Prob. 0.72) & Homocedastic errors \\
\hline Normality of errors & Jarque-Bera & 4.36 (Prob. 0.97) & Normality of errors \\
\hline Well specified & Ramsey (t-stat) & 0.17 (Prob. 0.86) & Well specified \\
\hline
\end{tabular}

Source: Synthesis of the Author from the results obtained on Eviews 9 
To confirm the absence of the absence of autocorrelation of residuals, we constructed the correlogram of squares of errors (Chart 4).

\section{Chart 4: The Corrologram of the Square of Residuals}

Correlogram of Residuals Squared

\begin{tabular}{|c|c|c|c|c|c|}
\hline \multicolumn{6}{|c|}{$\begin{array}{l}\text { Date: OB/29/18 Time: } 19: 44 \\
\text { Sample: } 1975 \text { 2014 } \\
\text { Included observations: } 37\end{array}$} \\
\hline Autocorrelation & Partial Correlation & $A C$ & PAC & Q-Stat & Prob* \\
\hline 1 1 1 & 1 1 1 & $1-0.075$ & -0.075 & 0.2247 & 0.635 \\
\hline 11 & 1 1 & 20.082 & 0.076 & 0.4990 & 0.779 \\
\hline $1=1$ & $=1$ & $3-0.094$ & -0.084 & 0.8733 & 0.832 \\
\hline 1. & - & $4-0.063$ & -0.082 & 1.0442 & 0.903 \\
\hline 11 & 11 & $\begin{array}{ll}5 & 0.047\end{array}$ & 0.053 & 1.1452 & 0.950 \\
\hline$=$ & i 1 & $6-0.075$ & -0.067 & 1.4066 & 0.965 \\
\hline 10 & 1 & $7-0.116$ & -0.151 & 2.0501 & 0.957 \\
\hline $\bar{a}$ & $\overline{1}$ & $8-0.075$ & -0.081 & 2.3290 & 0.969 \\
\hline $1=$ & = & $9-0.083$ & -0.086 & 2.6865 & 0.975 \\
\hline$=$ & $=$ & $10-0.150$ & -0.206 & 3.8867 & 0.952 \\
\hline ] & - & $11-0.153$ & -0.229 & 5.1795 & 0.922 \\
\hline 101 & & $12-0.082$ & -0.159 & 5.5718 & 0.936 \\
\hline = & $1=1$ & $13 \quad 0.194$ & 0.117 & 7.8416 & 0.854 \\
\hline 1 & I & $14 \quad 0.032$ & -0.031 & 7.9071 & 0.894 \\
\hline 101 & $i$ & $15 \quad 0.117$ & 0.014 & 8.7989 & 0.888 \\
\hline 101 & 1 = 1 & $16-0.057$ & -0.081 & 9.0256 & 0.912 \\
\hline
\end{tabular}

Source: Author from the results of the Eviews 9 software

The $Q$ Ljung-Box statistic indicates that the terms are not significantly different from 0 . The residuals are effectively uncorrelated.

In addition, the model is structurally stable and does not suffer from any point instability (Chart 6).

\section{Chart 5: Stability of the Model}
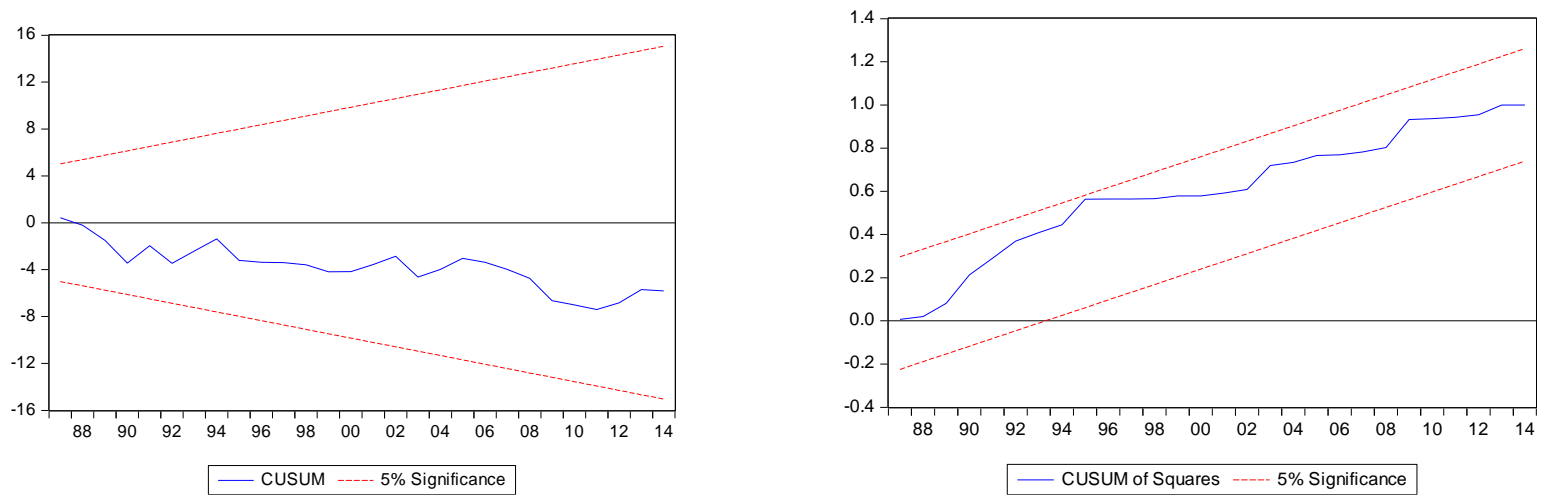

Source: Author from the results of the Eviews 9 software

\subsubsection{Bound test and the Toda-Yamamoto causality test}

Looking first at the results of the bounds test procedure (Table 6), we refer to the asymptotic critical values reported by Narayan (2005). The results indicate that the Fisher statistic (5.332474) is greater than the upper bound for the different significance thresholds. So we conclude that there is a long-term relationship between the different variables. 
Table 6: Cointegration Bound Test

\begin{tabular}{|l|c|c|c|c|c|}
\hline Model & F-statitic & K & Significance & I0 Bound & I1 Bound \\
\hline \multirow{3}{*}{$\begin{array}{l}\mathrm{LNCO}_{2} \text { et IDE, PIB, } \\
\text { LNOC, POP }\end{array}$} & \multirow{3}{*}{5.332474} & \multirow{3}{*}{4} & $10 \%$ & 2.2 & 3.09 \\
\cline { 4 - 6 } & & & $5 \%$ & 2.56 & 3.49 \\
\cline { 3 - 6 } & & & $1 \%$ & 2.88 & 3.87 \\
\hline
\end{tabular}

Source: Synthesis of the Author from the results obtained on Eviews 9

To determine the meaning of this relationship, the Toda-Yamamoto (1995) causality test is performed on the variables (Table 7).

Table 7: Toda-Yamamoto's Causality Test

\begin{tabular}{|c|c|c|c|c|c|c|c|}
\hline K & dmax & \multirow{2}{*}{$\begin{array}{c}\text { Variables } \\
\text { dépendantes }\end{array}$} & \multicolumn{5}{|c|}{ Variables explicatives } \\
\hline \multirow{6}{*}{5} & \multirow{6}{*}{3} & & Inco2 & Inoc & ide & pib & pop \\
\hline & & Inco2 & & $6.58(0.08)^{* *}$ & $5.17(0.15)$ & $1.08(0.78)$ & $1.43(0.69)$ \\
\hline & & Inoc & $12.01(0.007)^{*}$ & & $6.12(0.10)$ & $3.92(0.26)$ & $1.10(0.77)$ \\
\hline & & ide & $6.73(0.08)^{*}$ & $11.35(0.01)^{*}$ & & $1.90(0.59)$ & $3.54(0.31)$ \\
\hline & & pib & $6.20(0.10)$ & $7.62(0.05)^{*}$ & $0.20(0.97)$ & & $1.31(0.71)$ \\
\hline & & pop & $5.07(0.16)$ & $8.38(0.03)^{* * *}$ & $4.24(0.23)$ & $4.50(0.21)$ & \\
\hline
\end{tabular}

Source: Synthesis of the Author from the results obtained from the Eviews 9 software

(.) : Probabilities; ${ }^{*}$ significance at $1 \% ;{ }^{* *} 10 \%$ significance ; ${ }^{* * *}$ significance at $5 \%$.

The results show the absence of a causal relationship between $\mathrm{C02}$ emissions and FDI in the direction of FDI. This lack of relationship may reflect the low C02 emissions caused by FDI inflows into Côte d'Ivoire between 1975 and 2014. The diagram below summarizes the possible causal links between the variables.

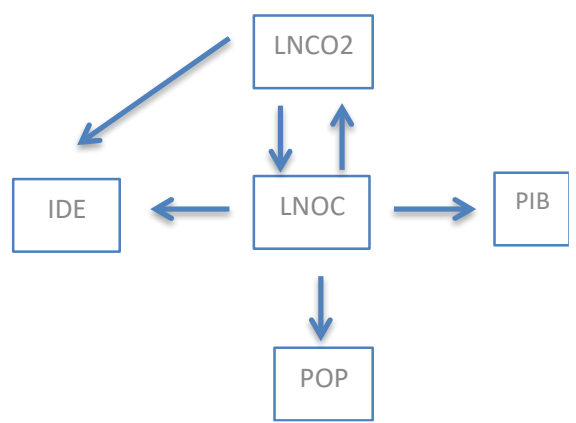

Two types of causality emerge: unidirectional and bidirectional causalities. For the first type of link, it is between trade openness and other variables, on the one hand, and between $\mathrm{CO}_{2}$ emissions and $\mathrm{FDI}$, on the other. More specifically, trade openness causes $\mathrm{CO}_{2}$ emissions, $\mathrm{FDI}$, growth and population. Likewise, $\mathrm{CO}_{2}$ emissions cause FDI inflows. As for bi-directional causality, it only concerns commercial openness and $\mathrm{CO}_{2}$ emissions where trade openness has an impact on $\mathrm{CO}_{2}$ emissions and this influences trade openness.

\subsubsection{ARDL Cointegration Test and Long-Term Form}

The cointegrating ARDL test and the long-term form confirmed these results. Indeed, the term u $(-1)$ corresponds to the delayed residue resulting from the long-term equilibrium equation. Its estimated coefficient is negative and significantly different from zero; confirming the existence of an error-correcting mechanism (Table 8). 
Table 8: The Cointegrating ARDL Test and the Long-Term Form

\begin{tabular}{|c|c|c|c|c|}
\hline \multicolumn{5}{|c|}{ Cointegrating Form } \\
\hline Variable & Coefficient & Std. Error & t-Statistic & Prob. \\
\hline $\mathrm{D}(\mathrm{IDE})$ & 0.000335 & 0.000106 & 3.152894 & 0.0038 \\
\hline $\mathrm{D}(\mathrm{IDE}(-1))$ & -0.000619 & 0.000150 & -4.133291 & 0.0003 \\
\hline $\mathrm{D}(\operatorname{IDE}(-2))$ & -0.000391 & 0.000097 & -4.030858 & 0.0004 \\
\hline $\mathrm{D}(\mathrm{PIB})$ & 0.004086 & 0.004922 & 0.830052 & 0.4135 \\
\hline $\mathrm{D}(\mathrm{POP})$ & 0.017543 & 0.210474 & 0.083350 & 0.9342 \\
\hline $\mathrm{D}(\mathrm{LNOC})$ & -0.289366 & 0.348617 & -0.830041 & 0.4135 \\
\hline$u(-1)$ & -0.955584 & 0.168255 & -5.679388 & 0.0000 \\
\hline \multicolumn{5}{|c|}{ Cointeq $=$ LNCO2 $-(0.0014 * I D E-0.0030 *$ PIB $+0.1652 * P O P-0.6625 *$ LNOC + 1.6262) } \\
\hline \multicolumn{5}{|c|}{ Long Run Coefficients } \\
\hline Variable & Coefficient & Std. Error & t-Statistic & Prob. \\
\hline IDE & 0.001408 & 0.000229 & 6.147385 & 0.0000 \\
\hline PIB & -0.003038 & 0.006244 & -0.486462 & 0.6304 \\
\hline POP & 0.165215 & 0.032696 & 5.053091 & 0.0000 \\
\hline LNOC & -0.662477 & 0.233791 & -2.833637 & 0.0084 \\
\hline C & 1.626238 & 1.074734 & 1.513154 & 0.1414 \\
\hline
\end{tabular}

Source: Synthesis of the Author from the results obtained from the Eviews 9 software

\subsection{Results Interpretation}

First of all, in the short term, the results show that all the coefficients have the expected sign. Specifically, they have a positive relationship between $\mathrm{CO}_{2}$ emissions and $\mathrm{FDI}$ whose associated coefficient is significantly different from zero. This result suggests that the contribution of $\mathrm{FDI}$ to $\mathrm{CO}_{2}$ emissions is minimal. Indeed, if $\mathrm{FDI}$ increases by 1 point $(100 \%)$ then $\mathrm{CO}_{2}$ emissions increase by $0.03 \%$. However, these effects reverse over time. In other words, FDI inflows one and two years ago were favorable to reducing $\mathrm{CO}_{2}$ emissions. For the other variables (GDP, POP and OC), their impact on $\mathrm{CO}_{2}$ emissions is not significant.

For the long term, the error correction coefficient $(\mathrm{u}(-1))$ indicates that when $\mathrm{CO}_{2}$ emissions In Ivory Coast are above or below their equilibrium value, corrected $95.5 \%$ by the effect of "feed back". In addition, a shock noted during a year is completely absorbed after 1 year 15 days. Moreover, all the coefficients have the expected sign except economic growth.

More specifically, the results suggest that the increase in FDI will lead to an increase in pollution with a coefficient significantly different from zero. Like the short term, this result also shows that the contribution of $\mathrm{FDI}$ to $\mathrm{CO}_{2}$ emissions is minimal in the long run because an increase in FDI of 1 point $(100 \%)$ leads to an increase in $\mathrm{CO}_{2}$ emissions of $0.14 \%$.

Such results are not necessarily the result of rigorous and strengthened regulation of the environment (Since 2013, the government has taken measures prohibiting the import, manufacture and use of plastic bags that have not yet been applied). They result mainly from the fact that the pollution intensive goods consumed in Ivory Coast are imported goods. This is for example the clinker that goes into the manufacture of cement. In fact, cement production has been rising steadily since 2012 in Ivory Coast. However, clinker, a source of $\mathrm{CO}_{2}$ emissions into the atmosphere is imported. This contributes to the low $\mathrm{CO}_{2}$ emissions due to FDI inflows in Ivory Coast.

Regarding economic growth, its impact on $\mathrm{CO}_{2}$ emissions is negative. This means that economic growth does not deteriorate the quality of the environment. However, the associated coefficient is not significantly different from zero.

On the other hand, the level of the population positively affects $\mathrm{CO}_{2}$ emissions with a coefficient significantly different from zero. Indeed, a $1 \%$ increases in the total population causes a $0.16 \%$ increase in $\mathrm{CO}_{2}$ emissions. The intuition of this result is that the larger the population, the more polluting the society is due to the human activities that contribute to the release of pollutants into the atmosphere.

As for commercial openness, its impact on $\mathrm{CO}_{2}$ emissions is negative and significantly different from zero. The coefficient of this variable, which is equal to -0.66 , suggests that a $10 \%$ increase in trade opening leads to a $6.6 \%$ reduction in $\mathrm{CO}_{2}$ emissions in Ivory Coast. This result is in line with the classic theory of international trade which states that highly polluting (capital intensive) industries remain in rich countries while low pollution (labor) industries relocate to poor countries. 


\section{CONCLUSION}

This article aimed to shed light on the links between $\mathrm{CO}_{2}$ emissions and FDI inflows in Ivory Coast between 1975 and 2014 , in a long-term perspective. We have shown that in the long term, $\mathrm{FDI}$ significantly increases $\mathrm{CO}_{2}$ emissions but their influence is very low. Thus, according to the results of Al-Mulali (2012) and Zhang (2011) and unlike those Al-Mulali and Tang (2013), FDI does not reduce $\mathrm{CO}_{2}$ emissions.

The improvement of the business, investment and trade climate in Ivory Coast, must be supported by social measures intended, in particular, to protect the health and safety of workers. Because environmental degradation due to an increase in emissions of $\mathrm{CO}_{2}$ supplies can have a negative impact on human health and bring about a decrease of economic growth. However, nevertheless, a better consideration of the link between $\mathrm{CO}_{2}$ emissions and FDI should be based on more accurate data on a fine decomposition of FDI that would significantly improve the relevance of the analysis.

\section{REFERENCES}

Al-Mulali, U. (2012). Factors affecting $\mathrm{CO}_{2}$ emission in the Middle East: a panel data analysis. Energy, vol.44, issue 1, p.564-569. DOI.org/10.1016/j.energy.2012.05.045

Al-Mulali, U., Tang, C. F. (2013). Investigating the validity of pollution haven hypothesis in the gulf cooperation council (GCC) countries. Energy Policy, vol.60, p.813-819. DOI.org/10.1016/j.enpol.2013.05.055

Arouri, M. E. H., Youssef, A. B., M'henni, H., Rault C. (2012). Energy consumption, economic growth and $\mathrm{CO}_{2}$ emissions in Middle East and North African countries. Energy Policy, vol.45, p.342- 349. DOI.org/10.1016/j.enpol.2012.02.042

Aschieri, A. et Lelievre M. (2012). La fin des terres : comment mangerons-nous demain ? Editions Scrineo, 163p.

Bahmaid, S. S. (2013). Study on foreign direct investment in education. International Journal of Advanced Trends in Computer Science and Engineering, vol.2, $n^{\circ} 1$, p.519-531

Blanco, L., Gonzalez, F., Ruiz I. (2013). The impact of FDI on CO2 emissions in Latin America. Oxford Development Studies, vol.41, $\mathrm{n}^{\circ} 1$, p.104121. DOI. $10.1080 / 13600818.2012 .732055$

Borhan, H., Ahmed E. M., Hitam M. (2012). The impact of $\mathrm{CO}_{2}$ on economic growth in Asean 8. Procedia-Social and Behavioral Sciences, vol.35, p.389-397.

Brou, Y. T. (2010). Variabilité climatique, déforestation et dynamique agro-démographique en Côte d’Ivoire. Sécheresse, vol.21, n4, p.1-6.

Dago, G. J. (2010). L'économie politique de l'investissement direct étranger (IDE) et le changement institutionnel : le cas de la Côte d'Ivoire. Thèse de doctorat en Sciences Economiques, Université Picardie Jules Verne d’Amiens (France).

Engle, R. F. et Granger, C. W. J. (1987). Cointegration and error correction representation : estimation and testing. Econometrica, vol.55, ${ }^{\circ} 2$, pp. 251-276.

Ghatak, S., Siddiki, J. (2001). The use of the ARDL approach in estimating virtual exchange rates in India. Journal of Applied Statistics, 28(5), 573-583.

Hitam, M., Borhan, H. (2012). FDI, growth and the environment : impact on quality of life in Malaysia. Procedia-Social and Behavioral Sciences, vol.50, p.333-342.

Ismaila, A. S. (2017). Foreign direct investment, education and economic growth in Nigeria. International Journal of Management Research \& Review, vol.7, Issue 4, n¹, april, p.384-397

Kheder, B. S., Zugravu N. (2012). Environmental regulation and French firm location abroad: an economic geography model in an international comparative study. Ecological Economics, vol.77, p.48-61.

Kivyiro, P., Arminen, H. (2014). Carbon dioxide emissions, energy consumption, economic growth, and foreign direct investment: causality analysis for Sub-Saharan Africa. Energy, 74, p.595-606. DOI.org/10.1016/j.energy.2014.07.025

Kizilkaya O. (2017). The impact of economic growth and foreign direct investment on CO2 emissions: the case of Turkey. Turkish Economic Review, vol.4, $\mathrm{n}^{\circ} 1, \mathrm{p} .106-118$.

Kyle, A. J., Miguel, D. R. (2015). Foreign direct investment and economic growth in Cote D'lvoire: a time series analysis. Business and Economic Research, 5(2), p.35-47.

Lee, J. W., Brahmasrene, T. (2013). Investigating the influence of tourism on economic growth and carbon emissions: evidence from panel analysis of the European Union. Tourism Management, vol.38, p.69-76.

Leiter, A. M., Parolini, A., Winner, H. (2011). Environmental regulation and investment : evidence from European industry data. Ecological Economics, vol.70, n4, p.759-770. DOI.org/10.1016/j.ecolecon.2010.11.013 
Mercan, M., Karakaya, E. (2015). Energy consumption, economic growth and carbon emission: dynamic panel cointegration analysis for selected OECD countries. Procedia Economics and Finance, vol.23, p.587-592.

Morrissey, O., Udomkerdmongkol, M. (2012). Governance, private investment and foreign direct investment in developing countries. World Development, vol.40, $\mathrm{n}^{\circ} 3, \mathrm{p} .437-445$.

Mucuk, M., Demirsel M. T. (2013). The effect of foreign direct investments on unemployment : evidence from panel data for seven developing countries. Journal of Business, Economics \& Finance, vol.2, n³, p.53-66.

Mutenyo, J., Asmah E., Kalio A. (2010). Does foreign direct investment crowd-out domestic private investment in Sub-Saharan Africa?. The African Finance Journal, vol.12, $n^{\circ} 1$, p. 27-52.

Narayan, P. (2005). The saving and investment nexus for Chile: evidence from cointegration tests. Applied Economics, 37(17), 1979-1990. DOI. 10.1080/00036840500278103

Nkechi, O. A. (2013). An econometric analysis of the impact of foreign direct investment on economic growth in Ghana: the role of human capital. International Journal of Humanities and Social Science Innovation, 2(8), p.12-20.

Pao, H., Tsai, C. (2011). Multivariate Granger causality b\&ween CO2 emissions, energy consumption, FDI (foreign direct investment) and GDP (gross domestic product): Evidence from a panel of BRIC (Brazil, Russian Federation, India, and China) countries. Energy, vol.36, issue 1, p.685-693. DOI.org/10.1016/j.energy.2010.09.041

Pesaran, M. H., Shin, Y. (1999). An autoregressive distributed lag modeling approach to cointegration analysis. In Strom, S., Holly, A., Diamond, P. (Eds.), Centennial Volume of Rangar Frisch, Cambridge University Press, Cambridge.

Pesaran, M. H., Shin, Y., Smith, R.J. (2001). Bounds testing approaches to the analysis of level relationships. Journal of Applied Econometrics, 16(3), 289-326. DOI. 10.1002/jae.616

Romer P. M. (1986) Increasing returns and long-run growth. The Journal of Political Economy, vol. 94, n5, Oct., pp. $1002-1037$.

Saray, M. O. (2011). The relationship of foreign direct investments and employment : Turkey case. Maliye Dergisi, $n^{\circ} 161$, p.381-403.

Strat, V. A., Davidescu A., Paul, A. M. (2015). FDI and the unemployment-a causality analysis for the latest EU members. Procedia Economics \& Finance, 23, p.635-643.

Tano, A. Maxime (2012). Conflits fonciers \& stratégies de sécurisation foncière au Sud-ouest ivoirien. Bulletin de l'Association de Géographes Français, 89ème année, (3), Terres \& tensions en Afrique, pp. 486-498.

Tang, C. F., Tan, B. W. (2015). The impact of energy consumption, income and foreign direct investment on carbon dioxide emissions in Vietnam. Energy, vol.79, p.447-454.

Thanh, L. T., Khuong N. D. (2017). Factors affecting $\mathrm{CO}_{2}$ emission in Vi\&nam: a panel data analysis. Organizations and Markets in Emerging Economies, vol.8, n², p.244-257.

Toda, H. Y., Yamamoto, T. (1995). Statistical inference in vector autoregressions with possibly integrated processes. Journal of Econometrics, Vol. 66, pp. 225-250. DOI.org/10.1016/0304-4076(94)01616-8).

Wooldridge, J. M. (2006). Introductory econometrics: a modern approach. MIT Press, Cambridge, MA.

Zeren, F. (2015). The impact of foreign direct investment on $\mathrm{CO}_{2}$ emission: pollution halo or pollution haven hypothesis?. Journal of Yasar University, 10(37), p.6442-6448.

Zhang, Y. J. (2011). The impact of financial growth on carbon emissions: an empirical analysis in China. Energy Policy, 39, 2197-2203. DOI. 10.1016/j.enpol.2011.02.026

Zhang, C., Zhou, X. (2016). Does foreign direct investment lead to lower $\mathrm{CO}_{2}$ emissions ? Evidence from a regional analysis in China. Renewable and Sustainable Energy Reviews, vol.58, p.943-952.

Zivin, J. G., Neidell, M. (2012). The impact of pollution on worker productivity. America Economic Review, december, vol.102, ${ }^{\circ} 7$, p.3652- $^{2}$ 3673 .

Zivot, E., Andrews, D. (1992). Further evidence of great crash, the oil price shock and unit root hypothesis. Journal of Business and Economic Statistics, vol.10, pp. 251-270. 